\title{
EVIDENCE BASED KURKUMIN DARI TANAMAN KUNYIT (Curcuma longa) SEBAGAI TERAPI KANKER PADA PENGOBATAN MODERN
}

\author{
Roihatul Mutiah \\ Jurusan Farmasi, Fakultas Sains dan Teknologi, Universitas Islam Negeri Maulana Malik \\ Ibrahim Malang, Malang Indonesia
}

\begin{abstract}
ABSTRAK
Kurkumin (diferuloylmethane $\left(\mathrm{C}_{21} \mathrm{H}_{20} \mathrm{O}_{6}\right)$ merupakan komponen berwarna kuningorange yang terkandung dalam tanaman Curcuma longa. Secara tradisional masyarakat Indonesia memanfatkan bagian rimpang tanaman tersebut sebagai salah satu komponen bumbu masakkan sehari-hari dan sebagai komponen jamu dari berbagai kondisi dan penyakit seperti panas, hepatitis, jerawat, infekasi bakteri, inflamasi, scabies dll. Studi in vivo dan in vitro menunjukkan bahwa kurkumin mempunyai berbagai aktivitas farmakologis antara lain antiinflamasi, antiviral, antibakteri, antifungal,antikanker, antioksidan, antidiabetes mellitus, antirheumatoid arthritis. Sedangkan studi klinik juga telah banyak dilakukan diantaranya pada kanker pancreas, kanker kolon, kanker payudara, dan multiple myeloma. Pada makalah ini penulis akan membahas tentang etnomedisin kunyit (Curcuma longa), studi pre-klinik baik secara in vitro maupun in vivo, studi klinik pada pasien dan mekanisme kerja senyawa kurkumin sebagai agen kemopreventif dan kemoterapi penyakit kanker.
\end{abstract}

Kata Kunci :Kurkumin. Curcuma longa, antikanker, evidence based

\section{A. PENDAhUluan}

Kanker adalah penyakit yang berhubungan dengan ketidakterkontrolnya kecepatan pertumbuhan sel abnormal dalam tubuh. Sel tersebut dapat menginvasi jaringan sel disekitarnya dan menyebar ke organ yang lain. Proses ini dikenal sebagai metastasis. Kanker juga biasa disebut tumor ganas atau neoplasma. Kanker sampai saat ini masih menjadi salah satu penyakit yang menjadi problem dunia. Kanker menyebabkan kematian yang cukup besar, ditahun 2008 tercatat 12,7 juta kasus kanker dan menyebabkan 7,6 juta kematian atau sekitar $13 \%$ dari semua kematian penduduk dunia disebabkan karena penyakit kanker (Jemal et al, 2011). Di Amerika kanker menjadi penyebab kematian ke-2 setelah penyakit kardiovaskuler tercatat 1.638 .910 kasus kanker dan menyebabkan 577.190 jiwa kematian di tahun 2012 (Siegel et al, 2012). Di Indonesia kanker merupakan penyebab kematian ke-6 setelah penyakit infeksi, kardiovaskuler, kecelakaan lalu lintas, kekurangan gizi dan penyakit bawaan (Tjindarbumi dan Mangunkusumo, 2002).

Terdapat beberapa pendekatan yang digunakan untuk mengobati kanker yaitu pembedahan, radiasi dan kemoterapi. Penggunaan metode tersebut tergantung pada jenis tumor dan stadium perkembangannya. Terkait dengan meningkatnya kejadian kanker tiap tahun, maka usaha untuk menemukan agen antikanker yang baru juga meningkat. Beberapa penelitian telah dilakukan untuk menemukan agen antikanker dari produk alam untuk mencegah dan menyembuhkan kanker.

Indonesia merupakan Negara terbesar setelah brazil yang kaya akan biodiversity termasuk tanaman obat. Salah satu tanaman tersebut adalah Curcuma longa. Tanaman ini telah dikenal luas dan banyak dimanfaatkan oleh masyarakat untuk mencegah dan mengobati berbagai kondisi ketidakseimbangan tubuh sejak zaman Kuno hingga sekarang. Selain dimanfaatkan sebagai obat, di Indonesia tanaman ini digunakan sebagai pewarna dan bumbu masak sehari-hari Bagian yang sering dimanfaatkan adalah rimpang diantaranya sebagai antiinflamasi, antiseptik, antoksidan (Duvoix et al, 2004).

Studi efek antikanker senyawa kurkumin dari tanaman Curcuma longa baik studi pre klinik maupun Klinik telah banyak dilakukan diantaranya dapat menghambat proliferasi sel kanker payudara MCF7 yang dikaitkan dengan kemampuannya dalam menghambat aktivitas cyclin D, Cyclin E, CDK2, CDK4, dan CDK6 serta kemampuannya dalam menginduksi apoptosis melalui penghambatan caspase- 9 (Li qiang et al, 2012). Selain itu studi klinik juga telah banyak dilakukan baik sebagai agen kemopreventif maupun kemoterapi diantaranya studi klinik pada kanker pancreas, kanker kolon, kanker payudara, dan multiple myeloma. Oleh karena itu menarik untuk dikaji tentang studi pre klinik dan studi klinik senyawa kurkumin dari tanaman Curcuma longa pada berbagai 
penelitian sebagai agen kemopreventif dan kemoterapetik. Pada makalah ini penulis akan membahas tentang etnomedisin Curcuma longa, studi pre-klinik baik secara in vitro maupun in vivo, studi klinik pada pasien dan mekanisme kerja senyawa kurkumin sebagai agen kemopreventif dan kemoterapi penyakit kanker.

\section{A. KUNYIT (Curcuma longa)}

1. Nama daerah

Kunyit mempunyai berbagai nama daerah yang berbeda-beda diantaranya: Sumatra; Kakunye (Enggano), Kunyet (Adoh), Kuning (Gayo), Kunyet (Alas), Hunik (Batak), Odil (Simalur), Undre, (Nias), Kunyit (Lampung), Kunyit (Melayu). Jawa: Kunyir (Sunda), Kunir (Jawa Tengah), Temo koneng (Madura). Kalimanta: Kunit (Banjar), Henda (Ngayu), Kunyit (Olon Manyan), Cahang (Dayak Panyambung), Dio (Panihing), Kalesiau (Kenya), Kunyit (Tidung). Nusa Tenggara: Kunyit (Sasak), Huni (Bima), Kaungi (Sumba Timur), Kunyi (Sumba Barat), Kewunyi (Sawu), Koneh, (Flores), Kuma (Solor), Kumeh (Alor), Kunik (Roti), Hunik kunir (Timor). Sulawesi: Uinida (Talaud), Kuni (Sangir), Alawaha (Gorontalo), Kolalagu (Buol), Pagidon (Toli-toli), Kuni (Toraja), Kunyi (Ujungpandang), Kunyi (Selayar), Unyi (Bugis), Kuni (Mandar). Maluku: Kurlai (Leti), Lulu malai (Babar), Ulin (Tanimbar), Tun (Kayi), Unin (Ceram),
Kunin (Seram Timur), Unin, (Ambon), Gurai (Halmanera), Garaci (Ternate). Irian: Rame (Kapaur), Kandeifa (Nufor), Nikwai (Windesi), Mingguai (Wandamen), Yaw (Arso).

2. Nama asing: turmeric

3. Sinonim : Curcuma domestica Val.

4. Klasifikasi Tumbuhan

Divisi : Spermatophyta

Subdivisi : Angiospermae

Kelas : Monocotyledonae

Bangsa : Zingiberales

Suku : Zingiberaceae

Marga : Curcuma

Spesies : Curcuma longa

Linn. (Syamsuhidayat dan Hutapea, 1991)

\section{Uraian Tumbuhan}

Habitus: Semak, tinggi $\pm 70 \mathrm{~cm}$.

Batang: Semu, tegak, bulat, membentuk rimpang, hijau kekuningan.

Daun: Tunggal, lanset memanjang, helai daun 3-8, ujung dan pangkal runcing, tepi rata, panjang 20-40 cm, lebar $8-12,5 \mathrm{~cm}$, pertulangan menyirip, hijau pucat.

Bunga: Majemuk, berambut, bersisik, tangkai panjang 16-40 cm, mahkota panjang $\pm 3 \mathrm{~cm}$, lebar $\pm 1,5 \mathrm{~cm}$, kuning, kelopak silindris, bercangap tiga, tipis, ungu, pangkal daun pelindung pulih, ungu. Akar: Serabut, coklat muda (Depkes RI, 2002).

B. KANDUNGAN SENYAWA AKTIF Curcuma Longa (Nahar dan Shaker, 2007)

Kandungan senyawa aktif Curcuma longa disajikan pada tabel di bawah ini:

\begin{tabular}{|c|c|}
\hline Komponen Isolat & Pustaka \\
\hline $\begin{array}{l}\text { (E)-1,7-Bis-(4-Hydroxy-methoxyphenil)-1- } \\
\text { heptene-3,5-dione } \\
(1 E, 4 E, 6 E)-1,7-B i s-(4-h y d r o x y-3- \\
\text { methoxyphenyl)-1,4,6-heptatrien-3-one } \\
(1 E, 4 E, 6 E)-1,7-B i s-(4-h y d r o x y p h e n y l)-1,4,6- \\
\text { heptatrien-3-one }\end{array}$ & $\begin{array}{l}\text { Nakayama et al., 1993; Sastry, 1970; } \\
\text { Ravindranath and Satyanarayana, 1980) }\end{array}$ \\
\hline Kurkumin & \\
\hline Cyclokurkumin & \\
\hline Demethoxykurkumin & \\
\hline $\begin{array}{l}\text { Dihydrokurkumin } \\
(E)-7-H y d r o x y-1,7-\text { bis-(4-hydroxy-3- } \\
\text { methoxyphenyl)-1-heptene-3,5-dione } \\
(E)-7-H y d r o x y-1,7-\text { bis-(4-hydroxy-3- } \\
\text { methoxyphenyl)-1-heptene-3,5-dione }\end{array}$ & $\begin{array}{l}\text { (Nakayama et al., 1993; Park and Kim, } \\
\text { 2002) }\end{array}$ \\
\hline $\begin{array}{l}(1 E, 6 E)-1-(4-H y d r o x y-3-m e t h o x y p h e n y l)-7-(3,4- \\
\text { dihydroxyphenyl)-1,6-hepta diene-3,5-dione }\end{array}$ & \\
\hline $\begin{array}{l}(1 E, 4 E)-1,5-B i s-(4-h i h y d r o x-3-m e t h o x y p h e n y l)- \\
\text { 1,4-pentadien-3-one } \\
(1 E, 4 E)-1-(4-H y d r o x y-3-m e t h o x y p h e n y l)-5-(4- \\
\text { hydroxyphenyl)-1,4-pentadien -3-one }\end{array}$ & $\begin{array}{l}\text { (Masuda et al., 1993; Park and Kim, } \\
\text { 2002) }\end{array}$ \\
\hline
\end{tabular}




\begin{tabular}{|c|c|}
\hline \multirow{2}{*}{\multicolumn{2}{|c|}{$\begin{array}{l}\text { á-Atlantone } \\
\beta \text {-Atlantone }\end{array}$}} \\
\hline & \\
\hline$\beta$-Bisabolene & $\begin{array}{l}\text { (Singh et al., 2002) } \\
\text { DNP, 2001: Ohshiro et al. 1990; }\end{array}$ \\
\hline 1,10-Bisaboladiene-3,4-diol & Kuroyanagi \\
\hline 2,10-Bisaboladiene-1,4-diol & et al., 1990; Ohshiro et al., 1990) \\
\hline Bisabola-3,10-diene-2-one & \\
\hline Bisacumol & \\
\hline Borneol & (Roth et al., 1998) \\
\hline Calebin A & (Park and Kim, 2002) \\
\hline Caffeic acid & (Roth et al., 1998) \\
\hline Camphene & \\
\hline Camphor & \\
\hline Cinnamic acid & \\
\hline p-Coumaric acid & \\
\hline & (Sacchetti et al., 2005; Bansal et al., \\
\hline$\beta$-Caryophyllene & 2002 \\
\hline a-Curcumene & Singh et al., 2002) \\
\hline 1,8-Cineole & \\
\hline$\beta$-Curcumene & \\
\hline Curcumenol & (DNP, 2001; He et al., 1998; Hikino et al., \\
\hline Curcumenone & 1968a; Ohshiro et al., 1990) \\
\hline Curdione & $\begin{array}{l}\text { (Roth et al., 1998) } \\
\text { He et al., 1998; Ohshiro et al., 1990; Kiso }\end{array}$ \\
\hline Curlone & et \\
\hline & al., 1983) \\
\hline Epi-curcumenol & (DNP, 2001) \\
\hline Curzerene & \\
\hline Curzerenone & (Roth et al., 1998) \\
\hline p-Cymene & (Grayson, 1998) \\
\hline Dehydrocurdione & (He et al., 1998; Ohshiro et al., 1990) \\
\hline 2,5-Dihydroxybisabola-3,10-diene & \\
\hline 4,5-Dihydroxybisabola-2,10-diene & \\
\hline Eugenol & Roth et al., 1998) \\
\hline$\beta$-Farnesene & (Singh et al., 2002) \\
\hline Germacrone-13-al & (Ohshiro et al., 1990; He et al., 1998) \\
\hline Germacrone-4,5-epoxide & \\
\hline 4-Hydroxybisabola -2,10-dien-9-one & $\begin{array}{l}\text { (Ohshiro et al., 1990) } \\
\text { (DNP, 2001; Ohshiro et al., 1990; }\end{array}$ \\
\hline 4-Hydroxy-3-methoxy-2,10-bisaboladien-9-one & $\begin{array}{l}\text { Kuroyanagi } \\
\text { et al., 1990; Ohshiro et al., 1990) }\end{array}$ \\
\hline 3-Hydroxy-1,10-bisaboladien-9-one & \\
\hline Procurcumadiol & \\
\hline Procurcumenol & \\
\hline 1-Epi-procurcumenol & \\
\hline Isoprocurcumenol & \\
\hline Isoborneol & (Roth et al., 1998) \\
\hline 8(17),12-Labdadiene-15,16 dial & \\
\hline Limonene & \\
\hline 4-Methoxy-5-hydroxy-bisabola-2,10-diene-9-one & \\
\hline 1-(4-Methylphenyl)ethanol & \\
\hline Myrcene & (Behura and Srivastava, 2004) \\
\hline$\alpha$-Phellandrene & $\begin{array}{l}\text { (Sacchetti et al., 2005; Bansal et al., } \\
\text { 2002) }\end{array}$ \\
\hline a-Pinene & (Roth et al., 1998) \\
\hline
\end{tabular}


$\beta$-Pinene

D-Sabinene

Syringic acid

Terpenolene

Terpinen-4-ol

ar-Turmerone (dehydroturmerone)

a-Turmerone

Turmerone

$\beta$-Turmerone

Turmeronol A

Turmeronol B

Turmerin (noncyclic polypeptide)

Vanillic acid

Zingiberene

Zedoarondiol

Ukonans A-D
(Grayson, 1998)

(Rothe et al., 1998)

(Sacchetti et al., 2005; Behura and

Srivastava,

2004; Bansal et al., 2002)

(Raina et al., 2002)

(Singh et al., 2002; Su et al., 1982)

(Golding et al., 1982

(DNP, 2001; Su et al., 1982)

(He et al., 1998)

(Imai et al., 1990)

(Srinivas et al., 1992)

(Rothe et al., 1998)

(Singh et al., 2002; Ohshiro et al., 1990) (DNP, 2001)

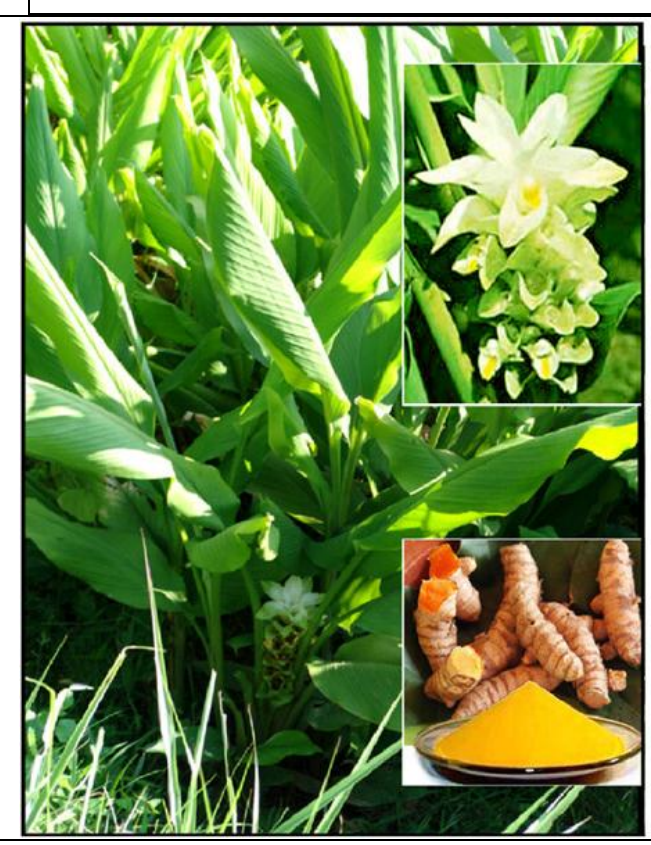<smiles>[R]c1cc(/C=C/C(=O)CC(=O)/C=C/c2cc([R])c(O)c([R7])c2)ccc1O</smiles>

Kurkumin (I)

Demethoxy kurkumin

$: \mathrm{R}^{\prime}=\mathrm{R} "=\mathrm{H}$

$\mathrm{R}^{\prime}=\mathrm{H}, \mathrm{R}$ "=H

Bis-demethoxykurkumin

$: \mathrm{R}=\mathrm{OMe}$

: R=R'=R"=H

Gambar 1. Curcuma longa L dan struktur kimia kurkumin

\section{SIFAT FISIKA-KIMIA KURKUMIN}

Kurkumin merupakan senyawa flavonoid yang tidak larut dalam air tetapi larut dalam ethanol, dimethilsulfoxid dan aseton. Curkumin mempunyai titik didih $183^{\circ} \mathrm{C}$ dan Rumus molekul $\mathrm{C}_{21} \mathrm{H}_{20} \mathrm{O}_{6}$, Berat molekul 368, $37 \mathrm{~g} / \mathrm{mol}$ (Sethi at al, 2009). Ada 3 jenis kurkumin yaitu kurkumin I (kurkumin), kurkumin II ( Demethoxykurkumin), kurkumin III (bisdemethoxykurkumin) (Nahar dan Sarker, 2007). secara spektrofotometri kurkumin mempunyai absorbansi maximal pada panjang gelombang $430 \mathrm{~nm}$ yang mengikuti hukum Lambert-Beer pada range konsentrasi 0,5 sampai $5 \mu \mathrm{g} / \mathrm{mL}$.larutan kurkumin $1 \%$ dalam pelarut aceton pada $\lambda$ 415-420 nm memberikan absorbansi 1650. (sethi et al, 2009).

\section{ETNOMEDISIN Curcuma longa}

Etnomedisin merupakan ilmu tentang penggunaan bahan alam sebagai sumber obat dalam mencegah, memperbaiki dan menyembuhkan kondisi sakit yang didasarkan pada budaya masyarakat. Akhir-akhir ini etnomedisin telah menjadi perhatian masyarakat akademis Indonesia untuk mengkaji lebih dalam tentang pengobatan yang telah dilakukan oleh nenek moyang kita. Salah satu tanaman yang telah banyak dikaji adalah Curcuma longa.

Curcuma longa telah dimanfaatkan oleh masyarakat Indonesia sebagai salah satu komponen ramuan jamu dalam mengatasi berbagai kondisi ketidakseimbangan tubuh. Dibawah ini diuraikan penggunaan kunyit (Curcuma longa) oleh masyarakat Indonesia secara tradisional yaitu sebagai obat :

1. Amandel 
Ramuan untuk obat amandel ini adalah : Rimpang kunyit $3 / 4$ jari di cuci bersih lalu diparut, di remas dengan air masak 2 sdm (sendok makan), diperas dan di saring, airnya di aduk dengan 1 butir kuning telur ayam dan kapur sirih sedikit lalu di minum. Diminum 1-2 kali sehari

\section{Asma}

Ramuan untuk obat asma adalah : rimpang kunyit 1 jari (di cuci dan diparut), isi buah pinang $1 / 2$ buah (ditumbuk halus), keduanya dicampur diremas dengan kapur sirih $40 \mathrm{ml}$ diperas dan disaring lalu diminum dua kali sehari $1 \mathrm{sdm}$

3. Bidur (urtikaria)

a. Rimpang kunyit $1 / 2$ jari dicuci bersih lalu diparut, diberi air masak $20 \mathrm{ml}$ dan madu 2 sendok teh $(5 \mathrm{ml})$ diperas lalu disaring kemudian dimunum 1-2 $x$ sehari

b. Rimpang kunyit 2 jari, rimpang cekur 2 jari, asam-lama 5 jari, dicuci lalu ditumbuk halus diremas dengan minyak kelapa $60 \mathrm{ml}$, duoleskan pada kulit yang gatal-gatal

4. Borok

a. Daun kunyit 3 lembar, daun urat 5 lembar, daun maja 5 lembar, daun buntut tikus 8 lembar, daun leng-lengan/daun setan 16 lembar, daun kepayang 6 lembar, dicuci dan ditumbuk halus, diremas dengan air perasan tembakau yang kental $1 / 2$ cangkir, untuk menurap borok (2 sehari sebanyak yang diperlukan)

b. Rimpang kunyit 2 jari, bawang merah 3 butir, dicuci lalu diparut, diremas dengan minyak kelapa $40 \mathrm{ml}$, dihangatkan di atas api seperlunya

5. Disentri

Rimpang kunyit 1 jari, asam lama dua jari, rimpang ceker ayam 2 jari, di cuci dan dipotong-potong seperlunya dan direbus dengan air bersih 3 gelas sampai tinggal setengahnya, sesudah dingin disaring lalu diminum, kemudian diminum $2 \times$ sehari $3 / 4$ gelas

6. Eksema

a. Rimpang kunyit 1 jari, dicuci bersih lalu diparut, diremas dengan air kapur sirih seperlunya untuk menurap kulit yang terkena eksema ( $2 x$ sehari sebanyak yang diperlukan) b. Rimpang kunyit 2 jari, kayu butbuta dua jari, daun salam 10 lembar, daun maja 6 lembar, daun senokembang 10 lembar, dicuci lalu ditumbuk halus, diremas dengan air garam seperlunya, untuk menggosok dan menurap kulit yang terkena eksema lalu dibebat ( $2 x$ sehari sebanyak yang diperlukan)

7. Frambusia

Ramuan ; rimpang kunyit 2 jari, kulit batang wudulan 3 jari, dicuci lalu ditumbuk halus-halus, diremas dengan minyak kemiri 3 sendok makan, untuk menggosok dan melumas kulit yang terkena frambusia (2x sehari sebanyak yang diperlukan).

8. Gabag /campak

Rimpang kunyit 3 jari, dicuci lalu diparut diremas dengan air garam seperlunya, untuk melumas bercakbercak pada kulit (2x sehari sebanyak yang diperlukan).

Dalam bentuk ramuan; rimpang kunyit 2 jari, kaolin (tanah liat) putih sebesar duku, dicuci lalu diparut diremas dengan air hangat $3 / 4$ gelas dan madu $3 \mathrm{sdm}$, diperas dan disaring lalu diminum $3 x$ sehari 2 sdm.

9. Kelemumur (Tinea furfuracea)

a. Rimpang kunyit 3 jari, dicuci lalu diparut, diberi air masak $3 \mathrm{sdm}$, diperas dan disaring, untuk menggosok kulit yang terkena kelemumur (2x sehari sebanyak yang diperlukan pagi dan siang sesudah mandi)

b. Ramuan ; rimpang kunyit 2 jari, rimpang lengkuas 2 jari, dicuci lau diparut, diremas dengan minyak jarak 4 sdm, untuk menggosok dan mengurut kulit yang terkena kelemumur (1-2 kali sehari sebanyak yang diperlukan, malam sebelum tidur)

10. Kencing darah

Ramuan ; daun jambu bijinyang masih muda 15 lembar, daun pascasudo 10 lembar, jintan 1 sdt, rimpang kunyit 1 jari, gula enau 3 jari, dicuci dan dipotong seperlunya, direbus dengan air bersih 4 gelas sehingga hanya tinggal kira-kira 3/4nya, suam-suam kuku disaring lalu diminum $3 x$ sehari $3 / 4$ gelas

11. Kudis

a. Ramuan : rimpang kunyit 2 jari, dicuci bersih lalu diparut, diremas dengan air kapur sirih seperlunya, untuk menggosok 
dan melumas kulit yang terserang kudis (2x sehari sebanyak yang diperlukan)

b. Ramuan ; rimpang kunyit 1 jari, kulit batang cariyu 2 jari, dicuci dan ditumbuk halus, diberi pati singkong 1 sdm, diremas dengan minyak kelapa $4 \mathrm{sdm}$, untuk menggosok dan menurap kulit yang terserang kudis ( $2 x$ sehari sebanyak yang diperlukan)

12. Radang rahim

a. Ramuan : daun jaha keeling $1 / 4$ genggam, daun sambang colok $1 / 4$ genggam, kayu rapat $1 / 2$ jari, rimpang kunyit 3 jari, rimpang kunci-pepat $3 / 4$ jari, gula enau 3 jari, dicuci dan dipotong-potong seperlunya direbus dengan air bersih $41 / 2$ gelas sehingga hanya tinggal kira-kira $1 / 2$ nya sesudah dingin disaring lalu diminum ( $3 x$ sehari $3 / 4$ gelas)

b. Ramuan: daun dadap srep 20 lembar, jamur-bromo 4 batang, daun tapak liman 16 lembar, daun buntut tikus 1 buah, rimpang kunyit 2 jari, dicuci lalu ditumbuk halus diremas dengan air panas $1 / 2$ gelas dan garam sebesar biji melinjo, untuk menurap bagian perut yang sakit.

13. Radang umbai usus

Rimpang kunyit $1 / 2$ jari, dicuci bersih lalu diparut, diberi air masak $1 \mathrm{sdm}$ dan madu 2 sdt diperas dan disaring lalu diminum.

14. Sekorbut

Rimpang kunyit $3 / 4$ jari, daun trawas 15 lembar, akar tapak liman 15 batang, kayu ules $3 / 4$ jari dau kaki kuda 10 lembar, daun sembung manis 10 lembar, daun saga manis 15 lembar, kayu-manis $3 / 4$ jari kulit batang sariawan $3 / 4$ jari, daun legetan 15 lembar, gula enau 3 jari, dicuci dan dipotong-potong seperlunya, direbus dengan air bersih 4 gelas sehingga hanya tinggal kira-kira $3 / 4$ nya, sesudah dingin disaring lalu diminum $(3 \mathrm{x}$ sehari $3 / 4$ gelas)

15. Sariawan

Rimpang kunyit $1 / 2$ jari, dicuci bersih lalu dikunyah-kunyah dengan garam seperlunya sesudah halus lalu ditelan (3x sehari)

16. Tekanan darah tinggi

Rimpang kunyit $1 / 2$ jari, dicuci bersih lalu diparut, diremas dengan madu 1 $\mathrm{sdm}$, diperas disaring lalu diminum (2-3x sehari)
17. Tidak haid lagi (menopouse)

Rimpang kunyit $1 / 2$ jari dicuci bersih lalu diparut, diberi air masak $2 \mathrm{sdm}$ dan garam sedikit, diperas disaring lalu diminum (2-3x sehari)

18. Cacar air

Rimpang kunyit 2 jari, rimpang temulawak 2 jari, dicuci lalu diparut, diremas dengan air batang pacing $1 / 2$ gelas, untuk melumas kulit yang terserang cacar air (2x sehari sebanyak yang diperlukan)

19. Cacing pita

Ramuan : rimpang temu-lawak $1 / 2$ jari, akar delima putih satu jari, rimpang kunyit $1 / 2$ jari, biji pinang $1 / 4$ buah, biji mentimun 1 sdt, daun ketepeng 4 lembar, adas $1 / 2$ sdt, pulosari $1 / 2$ jari, gula enau 3 jari, dicuci dan dipotong-potong seperlunya, direbus dengan air bersih $1 / 2$ gelas sehingga hanya tinggal kira-kira $3 / 5$ nya; sesudah dingin disaring lalu diminum.

20. Trachoma

Rimpang kunyit 1 jari, dicuci bersih lalu diparut, diberi air masak $2 \mathrm{sdm}$ diperas dan disaring, airnya diteteskan pada mata yang sakit (3$6 \times$ sehari 2-4 tetes)

21. Penyakit infeksi bakteri

Rimpang kunyit 3/5 jari, dicuci bersih lalu diparut, diberi air masak $1 \mathrm{sdm}$ dan madu 2 sdt diperas dan disaring lalu diminum ( $2 x$ sehari)

(Msrdisiswojo

Radjakmangunsudarso, 1968)

dan

\section{E. EVIDENCE BASED KURKUMIN SEBAGAI ANTIKANKER DALAM PENGOBATAN MODERN}

1. Studi Pra Klinik Kurkumin dan mekanisme kerja

Aktivitas antikanker Kurkumin telah banyak diteliti menggunakan berbagai pendekatan pada berbagai jenis kanker baik secara in vitro maupun in vivo. Kurkumin dapat dikembangkan sebagai obat antikanker yang poten. Aktivitas antikanker Kurkumin dikaitkan dengan kemampuannya sebagai penghambat COX maupun pada jalur signaling sel, baik melalui pemacuan apoptosis maupun cell cycle arrest dengan mempengaruhi produk gen penekan tumor maupun onkogen (Meiyanto, 1999). Selain itu, dikaitkan juga dengan kemampuannya sebagai penghambat proliferasi sel antioksidan, antiinflamasi, penghambatan karsinogenesis, immunomodulatory, antiestrogen, dan antiangiogenesis 
(Hatcher et al, 2008; strimpakos dan Sharma 2008; Bar-sela.2010)

Mekanisme kerja kurkumin sebagai antikanker melalui penghambatan induksi NF-kB telah banyak di teliti. Molekul NF-kB ditemukan pada tahun 1980 sebagai pengatur transkripsi gen immunoglobulin pada sel B. baru-baru ini ditemukan 5 anggota NF-kB pada mamalia yaitu p50, p65 (RelA),c-Rel dan RelB. Untuk aktivasi ekspresi gen molekul NF-kB adalah melalui pembentukan dimer kemudian memisah dengan I-kB inhibitor protein selanjutnya masuk dalam inti sel dan berikatan dengan DNA. Peningkatan aktivitas NF-kB yang tidak normal akan menyebabkan berbagai jenis kanker. Kurkumin mampu menghambat induksi NF-kB dan menekan proliferasi kanker payudara, kanker ovarium, kanker pancreas, leukemia dan multiple myeloma, kanker mulut, kanker kandung kemih dan kanker prostat (Lin Li dan Lin Kun, 2008). Kurkumin diketahui juga mampu mengatur produk gen NF-kB termasuk protein yang berhubungan dengan apotosis sel (Bcl-2, Bcl-x, TRAF), Pengatur siklus sel (cyclin D1, Cyclin D2), factor pertumbuhan (Interleukin, TNF- $\alpha$, VEGF), reseptor (CD40,CD44,CD86, CCR7,CXCL) dan Matrix metalloproteinase (MMP-2, MMP-9) aktivitas kurkumin terhadap sinyal NF-kB dirangkum pada tabel di bawah ini;

Tabel 2. Rangkuman molekul target kurkumin sebagai antikanker

\begin{tabular}{|c|c|c|}
\hline Molekul target & sistem & $\begin{array}{c}\text { Pustaka } \\
\text { (dalam Lin Li dan Lin Kun, 2008) }\end{array}$ \\
\hline $\begin{array}{l}\text { c-Jun/AP-1 } \\
\text { Protein Kinase C } \\
\text { NF-kB } \\
\text { IKK } \\
\text { TRAIL } \\
\text { Bcl-2, Bcl-XL } \\
\text { EGFR, HER-2, HER-3 } \\
\text { MMP-9 } \\
\text { HDAC } \\
\text { MAPK } \\
\text { COX-2 } \\
\text { TLR4 } \\
\text { Ets-1 } \\
\text { NNMT } \\
\text { ASPMase }\end{array}$ & $\begin{array}{l}\text { Tumor promotion } \\
\text { Tumor promotion } \\
\text { Tumor growth, } \\
\text { inflamasi } \\
\text { Tumor growth } \\
\text { Apoptosis } \\
\text { Anti apoptosis } \\
\text { Tumor growth } \\
\text { Tumor growth } \\
\text { Leukemia cell growth } \\
\text { Tumor growth, } \\
\text { inflamasi } \\
\text { Inflamasi } \\
\text { Immunitas } \\
\text { Tumor growth } \\
\text { Tumor growth } \\
\text { Tumor growth }\end{array}$ & $\begin{array}{l}\text { Huang et al, 1991, Lin, } 2007 \\
\text { Liu et al., } 2003 \\
\text { Dhandapani et al., } 2007 \text {; Chao et } \\
\text { al., } 2007 \\
\text { Kunnumakkara et al., } 2007 \\
\text { Khanbolooki et al., } 2006 \\
\text { Deeb et al., } 2007 \\
\text { Patel et al., } 2008 \\
\text { Lee et al., } 2007 \\
\text { Chen et al., } 2007 \\
\text { Chao et al., } 2007 \\
\text { Shakibaei et al., } 2007 \\
\text { Youn et al., } 2006 \\
\text { Yu \& Shah, } 2007 \\
\text { Tomida et al., } 2007 \\
\text { Cheng et al., } 2007\end{array}$ \\
\hline
\end{tabular}

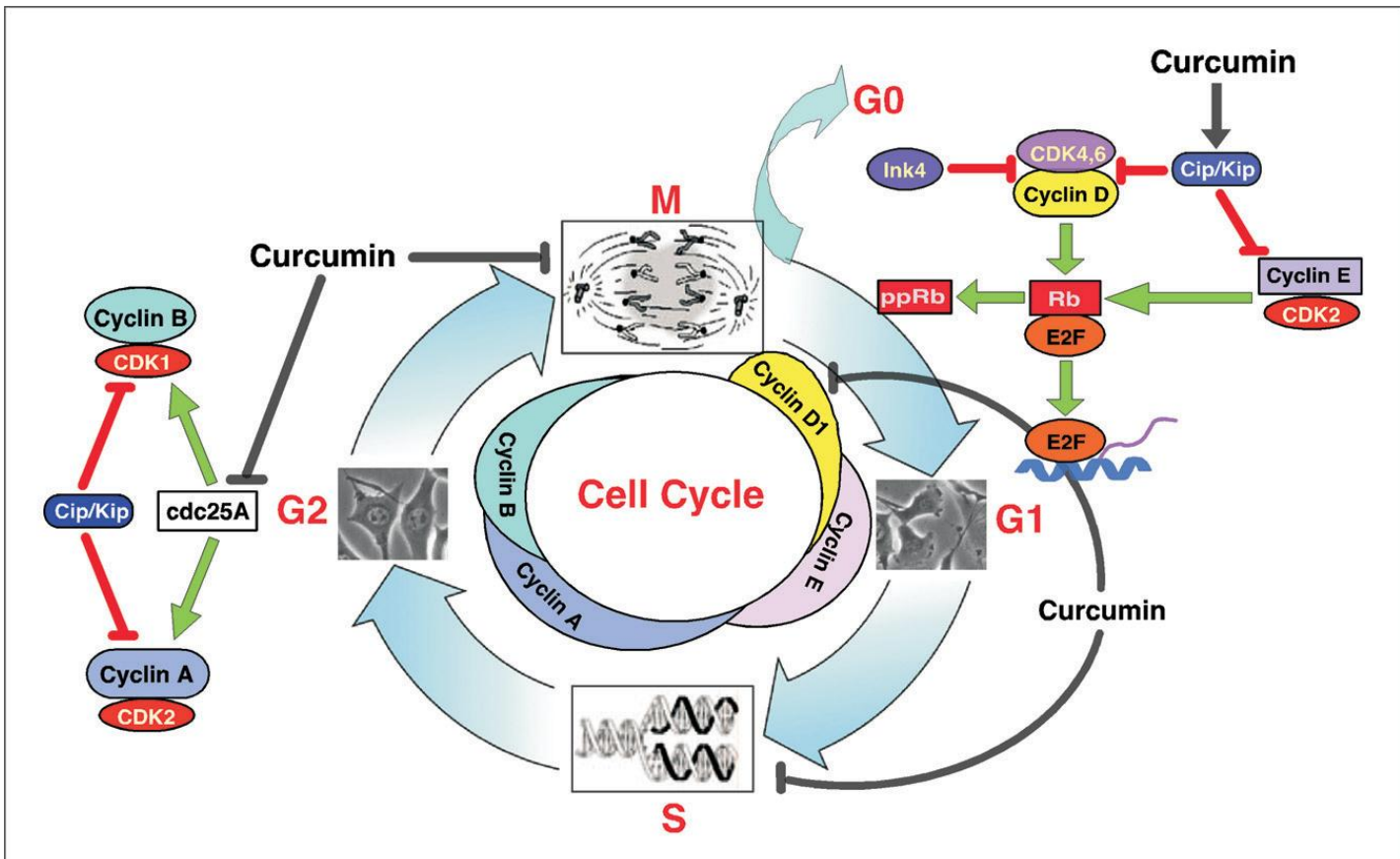

Gambar 3. Mekanisme kurkumin dalam menghambat proliferasi sel (Sa dan Das, 2008)

\section{a. Penghambatan proliferasi sel}

Proliferasi sel merupakan fungsi dari program daur sel. Daur sel terdiri dari empat fase yaitu G1 (Gap 1), S (fase sintesis dan replikasi DNA), G2 (Gap 2) dan $\mathrm{M}$ (Mitosis) (foster et al, 2001). 
Penghambatan proliferasi terkait dengan Cell Cycle Progression. Kurkumin telah dibuktikan mampu menginduksi cell cycle arrest pada fase G1, dan terlihat menurunkan prosentase sel memasuki fase S (Chen dan Huang, 1998; Bharti et al, 2003). Kurkumin juga dibuktikan pula mampu menghambat Cell Cycle Progression pada fase G2/M (van Erk et al, 2004). Penghambatan pada fase $G 1$ akan berakibat terhambatnya proses sintesis DNA (fase S).

Peran kurkumin dalam menghambat proliferasi sel di ilustrasikan pada gambar 3 .

\section{b. Efek antiinflamasi kurkumin}

Pada model uji pra klinik sel inflamasi akan melakukan infiltrasi ke dalam stromal microenvironment tumor, dimana dalam hal ini citokin pro inflamasi memainkan peranan yang sangat penting dalam proliferasi sel, invasi, migrasi dan metastasis, sehingga sel kanker dapat mencegah efek obat antiinflamasi seperti aspirin dan golongan salisilat yang lain (Elwood et al, 2009). Namun yang menarik pada penelitian efek antiinflamasi kurkumin secara in vitro menunjukkan bahwa kurkumin mampu menghambat enzim lipooksigenase dan cyclooksigenase, dimana enzim ini meningkat ekspresinya pada kondisi inflamasi dan kanker. Salah satu contoh obat antiinflamasi yang bersifat selektif menghambat COX-2 adalah celecoxib yang mempunyai kerja sinergis dengan kurkumin dimana obat ini mampu menghambat aktfitas katalisis isoenzim sedangkan kurkumin sendiri mampu menghambat transkripsi protein COX-2 glutathione peroksidase dan superoxide dismutase (Kunwar et al, 2009). Namun efek tersebut tergantung pada dua hal yaitu waktu dan konsentrasi yang berpengaruh terhadap perubahan stress oksidatif dan ekspressi gen antioksidan dalam inhibisi atau promosi kematian sel (kunwar et al, 2009). Yang menarik studi in vivo pada tikus menunjukkan adanya efek antioksidan kurkumin sehingga mampu memperbaiki kerusakan ginjal tikus yang diinduksi paracetamol (cekmen et al, 2009). Dose-dependent effect kurkumin juga dapat diketahui dari penelitian Kang et al dimana telah dilakukan studi terhadap sel hepatoma manusia (Hep 3B) yang diterapi dengan kurkumin selama 8 jam dimana pada konsentrasi terendah telah dilaporkan secara signifikan dapat menurunkan ROS namun pada konsentrasi yang tinggi kadar ROS meningkat (Kang et al, 2005).

\section{d. Aktivitas kurkumin pada tahapan karsinogenesis}

yang menyebabkan kadar COX-2 dalam sel menurun. Penelitian pada model kanker kolon menunjukkan bahwa Aktifitas antiinflamasi kurkumin adalah melalui penghambatan gen COX-2 yang menyebabkan pengurangan sintesis prostaglandin dan pengurangan pertumbuhan sel kanker (Goel et al 2001, ready et al, 2006). Kurkumin dan beberapa senyawa turunannya juga mampu menghambat transkripsi COX-1 (Plummer et al, 1999). Yang menarik kurkumin bekerja secara sinergis dengan golongan obat penghambat COX-2 yang lain seperti celcoxib (celbrex, Pfizer NY, USA) (Lev-Ari et al, 2008).

\section{c. Efek antioksidan kurkumin}

Fosforilasi oksidatif merupakan proses aerobik utama dalam sel yang terjadi dalam mitokondria dan diperantarai oleh sitokrom oksidase. Pada proses ini hasil akhirnya tidak hanya $\mathrm{H}_{2} \mathrm{O}$ tetapi juga Reactif Oksigen Spesies (ROS) yaitu superoxide anion $\left(\mathrm{O}_{2}^{-}\right)$, $\mathrm{H} 2 \mathrm{O} 2$, Radikal hidroksil $(\mathrm{OH})$. ROS tersebut memegang peranan penting dalam perkembangan kanker yaitu dalam perubahan DNA, peningkatan proliferasi sel, apoptosis, angiogenesis dan metastasis (LopezLazaro, 2008). Namun peningkatan ROS diatas ambang akan menyebabkan kematian sel, oleh karena itu kemungkinan ROS juga berperan dalam induksi kematian sel kanker.

Kurkumin telah ditemukan dapat menghambat ROS (Joe dan Lokesh, 1994, kesmungkinan hal ini berpengaruh terhadap keseimbangan enzim redoks seperti Proses karsinogenesis dibagi dalam tiga tahapan yaitu inisiasi, promosi dan progressi (Akram et al, 2010). Dari beberapa penelitian menunjukkan bahwa kurkumin menunjukkan efek pada ketiga proses tersebut. Pada model rodensia menunjukkan bahwa pemberian kurkumin dapat mencegah perkembangan kanker pada kulit, perut, kolon, liver, paru-paru dan payu dara (strimpakos dan Sharma, 2008). Penelitian yang telah dilakukan pada hewan coba Min Mouse yang di buat FAP (Familial Adenomatous Polyposis) menunjukkan pemberian kukukumin selama masa hidup terbukti dapat menurunkan adenoma dibanding control (Mahmoed et al, 2000). Penelitian lain pada hewan coba kanker kolon yang diinduksi azoxymethane menunjukkan adanya effek kurkumin pada tahap promosi dan progressi (samaha et al, 1997; Kawamori at al, 1999). Pada kedua studi in vivo tersebut pemberian kurkumin per oral dapat meningkatkan apoptosis sel dibanding control. 
Baru-baru ini kurkumin ditemukan dapat mengatur beberapa gen yang berperan dalam kanker. Matrix metalloproteinase (MMPs) berperan penting dalam invasi dan metastase sel kanker. Kurkumin ditemukan dapat menghambat migrasi sel kanker paru melalui inhibisi MMP-2 dan MMP-9 dan Vascular Endothelial growth factor (VEGF) (Lin et al,
2009). Pada model kanker kolon diketahui pula bahwa kurkumin mampu mencegah resistensi sel kolon kanker terhadap obat kemoterapi 5 fluorourasil dan oxaliplatin. Penurunan ketahanan/resistensi sel tersebut ditandai dengan penurunan aktivitas HER-2, IGF-IR (Insulin growth Factor-1 receptor), AKT, protein karsinogenesis (Patel et al, 2010).

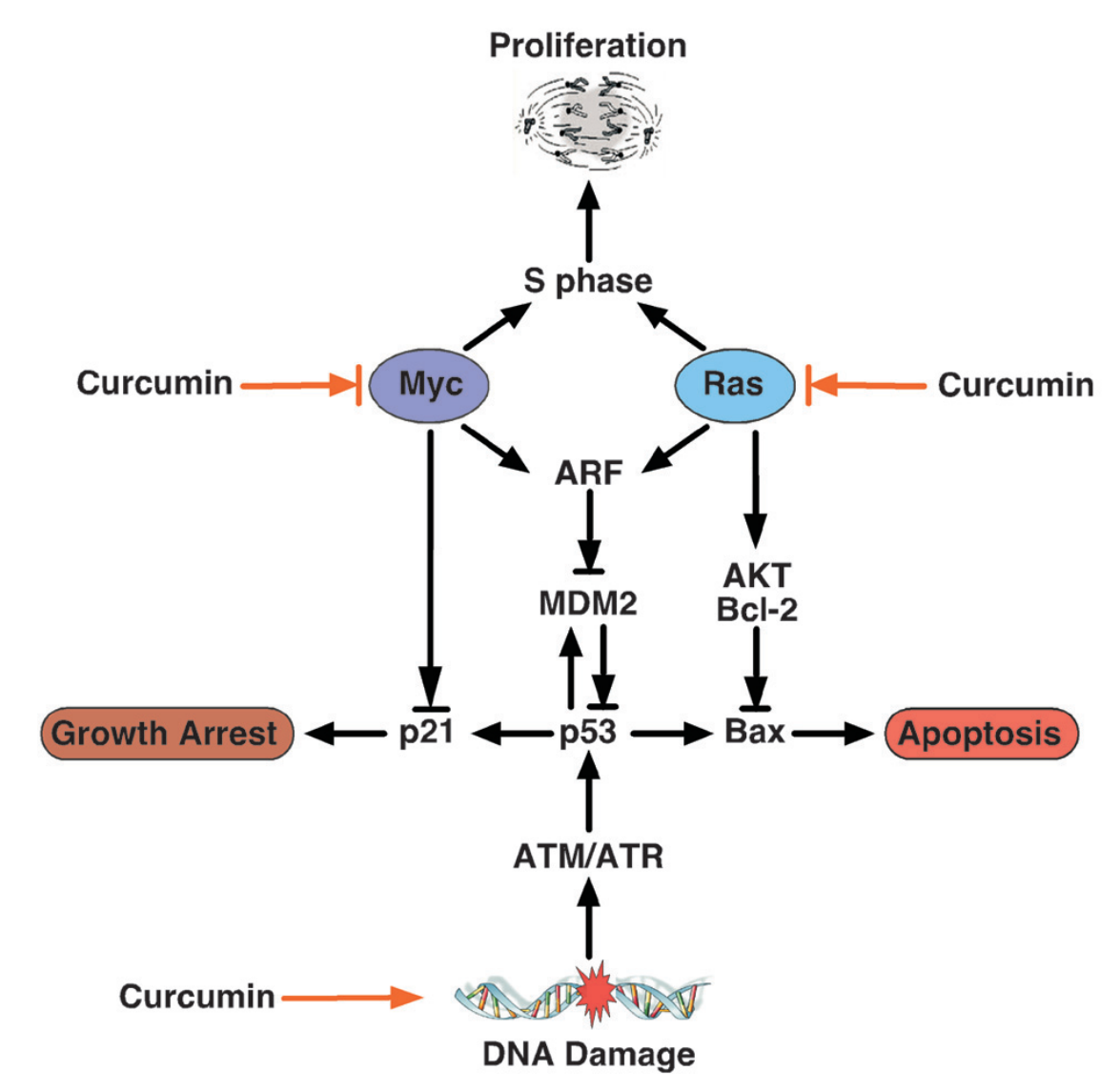

Gambar 4. Aktivitas kurkumin pada gen Growth factor (Sa dan Das, 2008)

Penelitian aktivitas kurkumin yang difokuskan pada aspek preventif dalam mencegah kanker telah banyak dilakukan. Penelitian efek antikanker kurkumin pada model human bladder cancer tikus orthotopic menunjukkan bahwa pemberian kurkumin monoterapi secara signifikan dapat menurunkan volume tumor kandung kemih, penurunan maksimum terlihat pada penggunaan kombinasi kurkumin dengan gemcitabine yang memberikan efek signifikan dibanding penggunaan gemcitabine monoterapi. Secara signifikan kurkumin juga dapat menurunkan proliferasi marker Ki-67 microvessel density CD31. Selain itu kurkumin juga dapat mencegah aktivitas NF-kB pada jaringan tumor, induksi apoptosis, penurunan ciclin D1, VEGF, Cox-2, c-myc, dan ekspresi Bcl-2 pada kanker kandung kemih (Tharakan et al, 2010). Pada penelitian yang mirip dengan model metastasis kanker kolon di ketahui bahwa kurkumin dapat menghambat kanker kolon cell line, kurkumin juga menunjukkan efek potensiasi dengan capecitabine dalam menginduksi apoptosis sel, menghambat aktifasi NF-kB dan penekanan pengaturan gen produksi NF-kB. Pada model nudemice kombinasi kurkumin dengan capecitabine telah ditemukan lebih efektif dari pada penggunaan monoterapi capecitabine dalam mereduksi volume tumor.

Pada hematological malignancies, secara in vitro dan pada model nude mice telah diketahui bahwa kurkumin mampu meningkatkan aktivitas thalidomide dan bartezomid pada terapi pasien dengan multiple myeloma. Hasil dari penelitian tersebut menunjukkan bahwa kurkumin menghambat proliferasi sel multiple myeloma dan pada model nude mice diketahui bahwa kurkumin mempunyai effek potensiasi dengan bortezomib dimana hal ini berhubungan dengan penekanan Ki-67, CD31 dan VEGF (Park et al, 2008; sung et al. 2009).

Aspek yang menarik ditemukan bahwa kurkumin mempunyai efek radioprotektif terhadap sel normal dan radiosensitifitas terhadap sel kanker. Mekanisme tersebut masih belum 
dimengerti secara jelas. Hal ini diduga bahwa kurkumin menurunkan stress oxidative dan menghambat transkripsi gen yang berhubungan dengan stress oxidative dan respon inflamasi sehingga mencegah efek radiasi terhadap sel normal. Radiosensitifitas terhadap sel kanker kemungkinan disebabkan oleh pengaturan gen yang berhubungan dengan kematian sel (Jagetia 2007, Akpolat et al, 2009). Kurkumin juga diketahui sebagai protector efek samping dari pemakaian kemoterapi. Hal tersebut di duga karena efek antioksidan dari kurkumin.

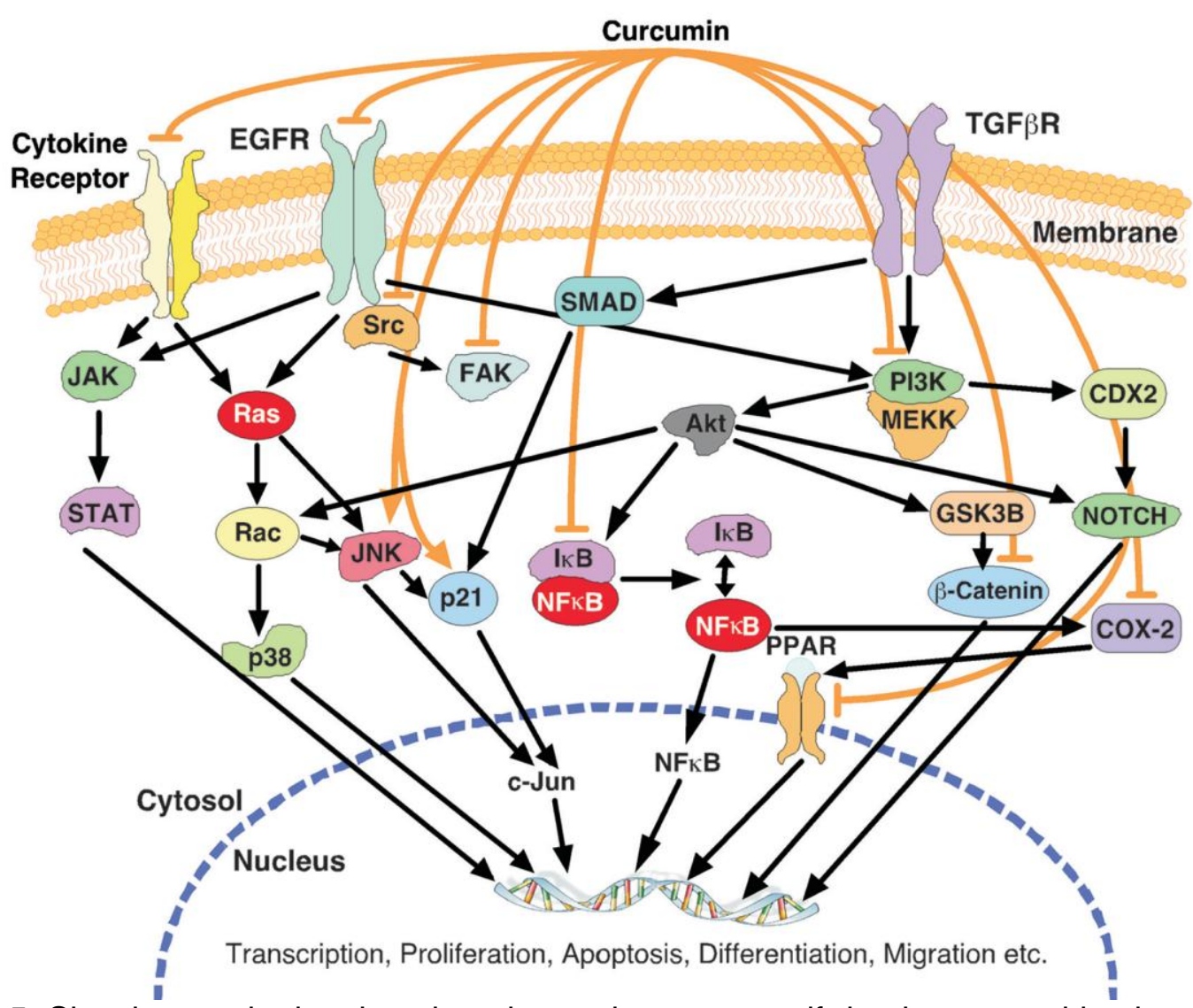

Gambar 5. Sinyal target kurkumin sebagai agen kemopreventif dan kemoterapi kanker (Sa dan Das, 2008).

Tabel 1. Ringkasan aktivitas kurkumin (Sela dan Schaffer, 2011)

\begin{tabular}{|l|l|l|}
\hline No & \multicolumn{1}{|c|}{ Aktivitas secara umum } & \multicolumn{1}{c|}{ Mekanisme } \\
\hline 1 & Immunologic modulation & $\begin{array}{l}\text { Modulasi factor pertumbuhan dan signaling } \\
\text { pathway }\end{array}$ \\
\hline 2 & Radiosensitifitas dan radioproteksi & Induksi enzim fase II \\
\hline 3 & $\begin{array}{l}\text { Aktifitas sbg } \\
\text { chemosensitizing }\end{array}$ & Efek kurkumin pada tumor suppressor P53 \\
\hline 4 & Chemopreventif dan chemoterapetic & $\begin{array}{l}\text { Penghambatan sitokin, penghambatan kinase } \\
\text { akv }\end{array}$ \\
\hline 5 & $\begin{array}{l}\text { Penghambatan angiogenesis dan } \\
\text { metastasis }\end{array}$ & $\begin{array}{l}\text { Penghambatan NF-kB } \\
\text {-penghambatan COX-2 } \\
\text {-penghambatan cyklin D1 } \\
\text { Penekanan Bcl-2 dan Bcl-XL } \\
\text { Mitogen activated protein kinase } \\
\text { Penghambatann STAT3 }\end{array}$ \\
\hline
\end{tabular}

\section{STUDI KLINIK Kurkumin}

Telah dilakukan studi klinik kurkumin pada pasien dengan berbagai tipe penyakit kanker diantaranya kanker pancreas, kanker kolon, kanker payudara, dan kanker jenis lain (multiple myeloma).

\section{a. Kanker pancreas}

Senyawa antimetabolit gemcitabine adalah standart kemoterapi untuk kanker pancreas. Namun terapi tersebut memberikan respon kurang dari 10\% pasien dengan efek survival kecil. Kombinasi kurkumin dengan gemcitabine ternyata memberikan efek potensiasi. Hal ini ditunjukan pada uji preklinik pada model kanker pancreas (Fryer at al, 2009). Epelbaum et al (2010) melakukan pengobatan pada 17 pasien dengan menggunakan kombinasi kurkumin dan gemcitabine. Dosis gemcitabine adalah $1000 \mathrm{mg} / \mathrm{m} 2$ yang diberikan seminggu sekali selama 7 minggu, diikuti 1 minggu istirahat, kemudian seminggu sekali selama 3 minggu diikuti 1 minggu istirahat. Sedangkan kurkumin diberikan 4 gram 2 kali sehari (pagi dan sore) selama treatmen 
dengan gemcitabine. Dari hasil penelitian tsb menunjukkan bahwa $45 \%$ pasien memberikan respon positif dan berada dalam kondisi yang stabil.

Dhillon at al (2010) telah melakukan studi pada pasien kanker pancreas fase I. Sebanyak 25 pasien diterapi dg 8 gram kurkumin per hari selama 2 bulan. Kemudian kadar sitokin serum di monitor. Sitokin yang dimonitor adalah (IL)-6, IL-8, IL-10 dan IL-1. Selain itu COX-2 dan ekspressi NF-kB pada darah mononuklear perifer juga dimonitor. 21 pasien dievaluasi responya: 1 pasien menunjukkan kondisi penyakitnya stabil selama 18 bulan. Dan tidak dilaporkan adanya toksisitas.

\section{b. Kanker kolon}

Studi klinik kanker kolon telah dilakukan oleh Sharma et al (2001) pada 15 pasien penderita kanker kolon fase-I dengan terapi 5-fluorourasil (5 FU). Pasien diberi variasi dosis ekstrak curcuma yaitu antara 4402200 mg per hari, yang setara dengan 36180 kurkumin terapi diberikan selama 4 bulan. Pemberian kurkumin secara per oral ditoleransi dengan baik, dan dilaporkan tidak adanya toksistas dosis yang diberikan. Namun metabolit kurkumin tidak terdeteksi dalam darah dan urin tetapi terdeteksi dalam feses pasien.

Gracea et al (2005) melakukan studi farmakodinamik pada 12 penderita kanker kolon. sebelum di bedah pasien di terapi dengan kurkumin dengan dosis $450 \mathrm{mg}$, $1800 \mathrm{mg}$ dan $3600 \mathrm{mg}$ per hari selama 7 hari. Sampel biopsy diambil pada 6-7 jam setelah pemberian kurkumin. Pemberian kurkumin pada dosis $3600 \mathrm{mg}$ diketahui dapat menurunkan M1G dari 4,8 $\pm 2,9$ tiap 107 nukleotida menjadi 2,0 $\pm 1,8$ per 107 nukleotida . Pada studi ini kurkumin tidak memberikan pengaruh pada protein COX-2. Penelitian ini menujukkan bahwa dosis $3600 \mathrm{mg}$ masih dalam batas aman bagi manusia.

Pada kasus yang lain dilaporkan bahwa terapi kombinasi oxaliplatin, 5 FU dan leucovorin yang diberikan bersama-sama dengan kurkumin pada dosis 5 gram per hari memberikan efek antikanker yang bagus tanpa adanya efek samping pada 5 bulan setelah terapi (Braumman et al, 2009).

\section{c. Kanker payudara}

Penelitian Fase I pada 14 pasien penderita kanker payudara yang di terapi kombinasi kurkumin dengan docetaxel telah dipubilkasikan oleh Bayet-Robert et al (2010). Docetaxel $\left(100 \mathrm{mg} / \mathrm{m}^{2}\right)$ diberikan setiap 3 minggu selam 6 siklus. Kurkumin diberikan secara oral mulai dosis $500 \mathrm{mg} /$ hari, 4 hari sebelum kemoterapi dan 2 hari sesudah kemoterapi dan dilanjtkan sampai dose-limiting toxicity. Maksimal dosis yang masih bisa di toleransi adalah 8000 mg/hari. Hasil menunjukkan bahwa 8 pasien memperlihatkan parsial respon dan 3 pasien dengan stabil desease.

\section{d. Kanker yang lain}

Telah dilaporkan bahwa penggunaan turmeric (curcuma longa) sebagai ointment pada kanker kulit, kanker payudara, kanker mukosa (oral cavity, vulva) dapat mngurangi luka kanker dan meningkatkan kualitas hidup pasien. Pengurangan bau (necrosis) pada borok kanker payudara telah dilaporkan pada $90 \%$ kasus.

\section{e. Toksisitas (Sela dan Schaffer, 2011)}

Kurkumin merupakan senyawa kimia yang ditoleransi tubuh dengan baik. Hal ini terbukti tidak memberikan efek toksik pada hewan (Shankar et al, 1980; NCI D 1996) ataupun pada manusia $(\mathrm{NCl} \mathrm{D}, 1996$; Chainani-Wu, 2003) walaupun pada dosis tinggi. Turmeric (Curcuma longa) menurut WHO adalah aman dikonsumsi setiap hari pada dosis $0,1-3 \mathrm{mg} / \mathrm{kg} \mathrm{BB}$.

Penelitian di Nepal menunjukkan bahwa konsumsi turmeric $1,5 \mathrm{~g}$ per orang per hari setara dengan 50 mg kurkumin per hari (Eigner and Scholz, 1999). Di India rata-rata penduduk mengkonsumsi $2-2,5 \mathrm{~g}$ per hari (setara dengan 60-100 mg per hari) dan dilaporkan bahwa tidak ada efek samping yang ditimbulkan (Cheng et al, 2001).

Studi pre klinik dan klinik telah terbukti bahwa kurkumin aman dan tingkat toksisitasnya sangat rendah. Studi di india menunjukkan bahwa pemberian 1,2-2,1 $\mathrm{g} /$ hari secara oral pada pasien reumatik arthritis selama 6 minggu tidak memberikan efek samping. Cheng et al memberikan terapi kurkumin $8 \mathrm{~g}$ per hari selama 3 bulan pada pasien preinvasif malignan dan terbukti tidak memberikan efek samping.

\section{F. KESIMPULAN}

Aktivitas kurkumin sebagai agen kemopreventif dan kemoterapi penyakit kanker telah terbukti secara ilmiah. Pada studi preklinik dengan pendekatan in vitro dan in vivo diketahui bahwa aktivitas kurkumin tersebut dikaitkan dengan kemampuannya dalam mengatur faktor transkripsi, faktor pertumbuhan, sitokin inflamasi, protein kinase dan enzim. Selain itu kurkumin juga mampu menghambat signaling sel baik melalui pemacuan apoptosis ataupun Cell Cycle Arrest.

Pada Studi klinik kurkumin terbukti efektif sebagai terapi penyakit kanker diantaranya sebagai terapi paliatif kanker, pencegahan kanker, terapi kuratif kanker kolon, kanker payudara, kanker pankreas dan multiple myeloma. Namun sebaiknya terapi dilakukan dalam bentuk kombinasi 
dengan obat antikanker yang lain (misal: gemcitabine, 5-fluorourasil). Hal ini bertujuan untuk meningkatkan efek sinergisme dan atau potensiasi obat antikanker tsb. Selain itu kurkumin juga telah terbukti menetralisir efek samping antikanker pada terapi kombinasi.

\section{DAFTAR PUSTAKA}

Akpolat, M., Kanter, M., \& Uzal, M. C (2009). Protective effects of kurkumin against gamma radiation-induced ileal mucosal damage. Archives of Toxicology, 83, 609-617

Akram M, Uddin S, Ahmed A, Usmanghani K, Hannan A, Mohiuddin E, Asif M, (2010), Curcuma Longa and kurkumin, a review article,.Rom.J.Biol-Plant Biol Volume 55, No.2, P 65-70

Bayet-Robert, M., Kwiatkowski, F., Leheurteur, M., et al. (2010). Phase I dose escalation trial of docetaxel plus kurkumin in patients with advanced and metastatic breast cancer. Cancer Biology\& Therapy, 9, 8-14.

Braumann, C., Guenther, N., Loeffler, L. M, \& Dubiel, W. (2009). Liver metastases after colonic carcinoma-palliative chemotherapy plus kurkumin. International Journal of Colorectal Disease,24, 859-860.

Cekmen, M., Ilbey, YO., Ozbek, E, et al. (2009). Kurkumin prevents oxidative renal damage induced by acetaminophen in rats. Food and Chemical Toxicology: An International Journal Published for the British Industrial Biological Research Association, 47, 1480-1484.

Cheng, A. L., Hsu, C. H., Lin, J. K., et al. (2001). Phase I clinical trial of kurkumin, a chemopreventive agent, in patients with high-risk or pre-malignant lesions. Anticancer Research, 21,2895-2900.

Dhillon, N., Aggarwal, B. B., Newman, R A., et al. (2008). Phase II trial of kurkumin in patients with advanced pancreatic cancer. Clinical cancer research: An official journal of the American Association for Cancer Research, 14, 4491-4499.

Duvoix A, Blasius $R$, Delhalle $S$, Schnekenburger M, Morceau F, Henry E, Dicato M, Diederich M. (2005), Chemopreventive and therapeutic effect of kurkumin. Science Direct, Cancer Letter. P 181-190
Elwood, P. C., Gallagher, A. M., Duthie, G. G., et. al. (2009). Aspirin, salicylates, and cancer. Lancet, 373, 1301-1309.

Epelbaum, R., Schaffer, M., Vizel, B., et al. (2010). Phase II study of kurkumin and gemcitabine in patients with advanced pancreatic cancer. Nutrition and Cancer, 8, 1137-1141.

Fryer, R. A., Galustian, C., \& Dalgelish, A. G. (2009). Recent advances and developments in treatment strategies against pancreatic cancer. Curr Clinical Pharmacology, 4, 102-112.

Garcea, G., Berry, D. P., Jones, D. J, et al. (2005). Consumption of putative chemopreventive agent kurkumin levels in the colorectum and pharmacodynamic consequences. Cancer Epidemiology, Biomarkers \& Prevention: A publication of the American Association for Cancer Research,cosponsored by the American Society of Preventive Oncology, 14, 120125.

Goel, A., Boland, C. R., \& Chauhan, D. P. (2001). Specific inhibition of cyclooxygenase-2 (COX-2) expression by dietary kurkumin in HT-29 human colon cancer cells. Cancer Letters, 172,111-118.

Han S.S, Keum S.Y, Seo J.H, Surh J.Y, (2002),Kurkumin supresses Activation of NF-kB and AP-1 Induce by Phorbol Ester in Cultured Human Promyeloccytic Leukemia Cells, Journal of Biochemistry and Molecular Biology, Vol.35, No 3, pp.337-342

Jemal A, Bray F, Center MM, Ferlay J, Ward E, Forman D. 2011. Global cancer statistics. CA Cancer J Clin. Mar -April Vol 2 No 61 hal $69-90$

Jagetia, G. C. (2007). Radioprotection and radiosensitization by kurkumin. Advances in experimental Medicine and Biology, 595, 301-320.

Joe, B., \& Lokesh, B. R. (1994). Role of capsaicin, kurkumin and dietary n-3 fatty acids in lowering generation of reactive oxygen species in rat peritoneal macrophages. Biochimica et Biophysica Acta, 1224, 255-263.

Kang, H. J., Lee, S. H., Price, J. E, et. al. (2009). Kurkumin suppresses the paclitaxelinduced nuclear factor-kappaB in breast cancer cells and potentiates the growth inhibitory effect of paclitaxel in a breast cancer 
Kawamori, T., Lubet, R., Steele, V. E., et al. (1999). Chemopreventive effect of kurkumin, a naturally occurring antiinflammatory agent, during the promotion/progression stages of colon cancer. Cancer Research, 59, 597-601.

Kunwar, A., Sandur, S. K., Krishna, M., et al. (2009). Kurkumin mediates time and concentration dependent regulation of redox homeostasis leading to cytotoxicity in macrophage cells. European Journal of Pharmacology, 611, 8-16.

Lev-Ari, S., Lichtenberg, D., \& Arber, N. (2008). Compositions for treatment of cancer and inflammation. Recent Patents on Anticancer Drug Discovery, 3, 55-62.

Li qiang $\mathrm{H}$, Jin JL, Wu F, Li yX, You SJ,Cao HZ, Li D, Xu P.Y. (2012). Effect of Kurkumin on Proliferation, Cell cycle and caspase and MCF-7 cells, African Journal of Pharmacy and Pharmacology Vol 6(12).PP.864-870

Lin Li C dan Lin Kun j, (2008), kurkumin : a Potential Cancer Chemopreventif Agent Through Supressing NF-kB signaling, Journal of Cancer Molecules 4(1), p 11-16

Lin, S. S., Lai, K. C., Hsu, S. C, et al. (2009). Kurkumin inhibits the migration and invasion of human A549 lung cancer cells through the inhibition of matrix metalloproteinase-2 and -9 .

López-Lázaro, M. (2008). Anticancer and carcinogenic properties of kurkumin: Considerations for its clinical development as a cancer chemopreventive and chemotherapeutic agent. Molecular Nutrition \& Food Research, 52(Suppl..1), S103-S127.

Mahmoud, N. N., Carothers, A. M., Grunberger, D., et al. (2000). Plant phenolics decrease intestinal tumors in an animal model of familial adenomatous polyposis. Carcinogenesis, 21, 921-927.

Nahar L, Sarker D.S, (2007), Phytochemistry of The Genus Curcuma dalam Ravindran, P.N., Babu N.K, Sivaraman K, Turmeric, The Genus Curcuma, CRC Press hal 71-101

Park, J., Ayyappan, V., Bae, E. K., et al. (2008). Kurkumin in combination with bortezomib synergistically induced apoptosis in human multiple myeloma U266 cells. Molecular Oncology, 2, 317-326.
Plummer, S. M., \& Holloway, K. A., (1999). Manson MM, et al. Inhibition of cyclooxygenase 2 expression in colon cells by the chemopreventive agent kurkumin involves inhibition of NFkappaB activation via the NIK/IKK signaling

Reddy, S., Rishi, A. K., Xu, H., et al. (2006). Mechanisms of kurkumin- and EGFreceptor related protein (ERRP)-dependent growth inhibition of colon cancer cells. Nutrition and Cancer, 55,185-194.

Siegel R, Naishadham D, Jemal A. 2012.Cancer Statistic. CA: A Cancer Journal for Clinicians Volume 62 Nomer 1 hal $10-29$

Samaha, H. S., Kelloff, G. J., Steele, V., et al. (1997). Modulation of apoptosis by sulindac, kurkumin, phenylethyl-3methylcaffeate, and 6-phenylhexyl isothiocyanate: Apoptotic index as a biomarker in colon cancer chemoprevention and promotion. Cancer Research, 57, 1301-1305.

Sela B.G dan Schaffer, (2011), An Evidence-Based Perspective of Curcuma Longa (Turmeric) For Cancer Patient, Spinger Science. P 225-243

Sethi G, Sung and Aggarwal B.B., (2009) The Role of Kurkumin in Modern Medicine. Herbal drug to modern Medicine. Springer. P 114-121

Shankar, T., Shantha, N. V., Ramesh, H. P., et al. (1980). Toxicity studies on turmeric (Curcuma longa): Acute toxicity studies in rats, guinea pigs and monkeys. Indian Journal of Experimental Biology, 18, 73-75.

Sharma, R. A., Euden, S. A., Platton, S. L., et al. (2004). Phase I clinical trial of oral kurkumin: Biomarkers of systemic activity and compliance. Clinical cancer research: An official journal of the American Association for Cancer Research, 10 6847-6854.

Sung, B., Kunnumakkara, A. B., Sethi, G., et al. (2009). Kurkumin circumvents chemoresistance in vitro and potentiates the effect of thalidomide and bortezomib against human multiple myeloma in nude mice model. Molecular Cancer Therapeutics, 8, 959-970.

Tharakan, S. T., Inamoto, T., Sung, B., et al. (2010). Kurkumin potentiates the antitumor effects of gemcitabine in an orthotopic model of human bladder cancer through suppression of proliferative and 
angiogenic biomarkers. Biochemical Pharmacology, 79, 218-228.

Tjindarbumi D, Mangunkusumo R. 2002. Cancer in Indonesia, present and future. Jpn J Clin Oncol. Mar 31 hal 17-21
Vascular Endothelial Growth Factor (VEGF). Cancer Letters, 285, 127-133.

WHO 2011, Cancer, World Health Organization, Switzerland. 2011. http://www.who.int/mediacentre/factsheet s/fs297/e 